\title{
Research and practice about car body and comfort system service curriculum standards connect from secondary to higher vocational school
}

\author{
Yan Liu \\ Dalian Vocational and Technical College, Dalian Liaoning province, China \\ 1265604464@qq.com
}

Keywords: connection from secondary to higher vocational school, car body and comfort system service , curriculum standard

\begin{abstract}
Connect from secondary to higher vocational school is the trend of times, it gives vocational school students a chance to relearn. However, the essence and key problem is the curriculum connection, it is the crux to realize sustainable and harmonious development of secondary and higher vocational school. Take the curriculum standard of 《car body and comfort system service》 of vehicle inspection and maintenance professional connected from secondary to higher vocational school, according to the automotive professional vocation ( post ) group and professional ability analysis, to make sure the connection content about course objectives, course content , professional ability, teaching methods and teaching evaluation suggestion, make that when secondary and higher vocational school train students, they can have clear teaching target , reasonable content, avoid repetition, ability can realize progressive, to provide important basis to talent development of connection from secondary to higher vocational school.
\end{abstract}

\section{Introduction}

Connect from secondary to higher vocational school is a new historical proposition of the development vocational education, which is a necessary requirement of the development of vocational education. The basic function of vocational education is to train technical skilled personnel, the purpose of training the different level of technical skilled personnel by secondary and higher vocational school is to serve social development. At present, the education of the secondary and higher vocational education cannot comply with the vocational education growing regulation in China. Development integration programs of the training skilled personnel through secondary to higher vocational school, resulting in a lack of hierarchy in training objectives, different caliber in professional setting, cannot achieve the continuity of the course, order and integration and result in the practical difficulties on convergence. Secondary and higher vocational education are two levels of education,

Have relative independence and differences in personnel training goals and specifications and professional quality and comprehensive professional quality. Connect from secondary to higher vocational school must achieve progressive convergence on goals, level, professional and curriculum structure. Reasonable convergence of the course is the core issue. Course convergence not only follows the law from the prosecution to complex but also avoids content duplication, waste of resources. So setting reasonable course goals, course content, professional ability, appropriate teaching methods and evaluation system is important to reach convergence in the true sense. In this paper, body and comfort systems service vocational courses as an example to tell the study and practice of the curriculum Standards. 


\section{The design idea of the body and comfort system service curriculum standards connect from secondary to higher vocational school}

According to different occupations (jobs) groups, determine vocational skills, training objectives, training objectives and ability structure of the secondary and higher vocational education to achieve reasonable convergence. According to the characteristics of specialty, reasonable locating course, forming the corresponding curriculum objectives, selecting course content for target, designing integration of theory and practice of teaching methods teaching quality evaluation system are study content, and form the curriculum standards connect from secondary to higher vocational school.

After business research, from work field, define the students of the secondary vocational school only do general maintenance work, replacement auto parts and simple mechanical maintenance work after graduation, only meet the needs of the "automotive nurse", so secondary vocational schools should develop skilled personnel.

And higher vocational students can service auto mechanics, electrical, electronic control systems, develop a maintenance program and technology is more comprehensive, can meet the need of the "automotive doctor", so higher vocational schools should develop higher-quality technical skilled personnel. According to research, the career goals of body and comfort systems service of secondary vocational school is mastering the operation method of the vehicle's electrical system and carrying out routine maintenance. The career goal of the higher vocation school is mastering the vehicle's electrical system common fault detection and repair methods.

After determining professional core skills and quality requirements of the secondary and higher vocational school, establish course objectives, learning content etc., achieve convergence in the true sense.

\section{The specific content of the body and comfort system service curriculum standards connect from secondary to higher vocational school}

(1) The course objectives convergence

Course objectives resolve the question of the "learning what", that is, they should teach students' knowledge and skills. Course objectives connect from secondary to higher vocational school must be continuous, sequential. In curriculum standards of the body and comfort system service connect from secondary to higher, clearly different in learning objectives, and reflects the progressive ability. Course objectives of the secondary are to master the composition, working principle, function of the automotive body electrical system. Course objectives of the higher are to acquire knowledge of the common fault detection and repair methods.

(2) The course content convergence

Secondary and higher vocational educations are two different levels of qualifications, course content in difficulty, depth, breadth and capabilities are differential. They should have a clear learning precinct and logical gradient, although they are the adjacent levels, they are also therethrough. From two levels of the educational specifications, studying the corresponding of course content and training objectives, and then according to teaching objectives configure the appropriate course content, so that the course content is more scientific and rational. According to the principle of hierarchy and gradient, selects the course content. the nature of the course, total hours, course content, knowledge points are shown in Table 1. 
Table 1, the nature, total academic hours, and course content, knowledge points of vocational courses

\begin{tabular}{|c|c|}
\hline secondary vocational school & higher vocational school \\
\hline $\begin{array}{l}\text { Course Nature: } \\
\text { main Professional course }\end{array}$ & $\begin{array}{l}\text { Course Nature: } \\
\text { main Professional course }\end{array}$ \\
\hline academic hours : 75 & academic hours : 75 \\
\hline $\begin{array}{l}\text { knowledge points: } \\
\text { composition, works and functions of the } \\
\text { automotive body safety and comfort } \\
\text { systems, etc. }\end{array}$ & $\begin{array}{l}\text { knowledge points: } \\
\text { the fault detection and repair methods of } \\
\text { the automotive body safety and comfort } \\
\text { systems, etc. }\end{array}$ \\
\hline course content : & course content \\
\hline $\begin{array}{l}\text { 1.components, structure, circuit } \\
\text { analysis, and basic maintenance of the } \\
\text { automotive lighting, signal system; } \\
\text { 2.components, structure, circuit analysis } \\
\text { and basic maintenance of the } \\
\text { automotive instrumentation system; } \\
\text { 3.composition,structure,circuit analysis } \\
\text { and basic maintenance of the } \\
\text { automotive electrical device } \\
\text { 4.components, structure,circuit analysis, } \\
\text { and basic maintenance of the auto body } \\
\text { electronic control system (airbags, } \\
\text { alarm, audio, GPS, reversing radar) }\end{array}$ & $\begin{array}{l}\text { 1.the fault detection and repair of the } \\
\text { automotive lighting, signal systems } \\
\text { 2.the fault detection and repair of the } \\
\text { automotive instrumentation system } \\
\text { 3.the fault detection and repair of the } \\
\text { automotive electrical device } \\
\text { 4.the fault detection and repair of the } \\
\text { auto body electronic control system } \\
\text { (airbags, alarm, audio, GPS, reversing } \\
\text { radar) } \\
\text { 5.components, structure, circuit analysis, } \\
\text { and basic maintenance of the car } \\
\text { network system }\end{array}$ \\
\hline
\end{tabular}

(3) Professional competence converge

Professional competence converging of the secondary and higher is close and progressive.

The skills and knowledge requirements of the relevant professional qualification certificates embed teaching contents, so that the secondary and higher vocational students can obtain different progressive vocational certificates, they can get on the convergence. In the car repair class, professional qualifications include: car repairman, vehicle maintenance electrician, car repair sheet metal and car repair painting, and the level of each certificate is divided into beginner, intermediate, advanced, technician and senior technicians. In higher vocational colleges, students can obtain advanced certificate. In secondary vocational schools, students can obtain intermediate certificate.

In the curriculum, secondary vocational students can achieve proper operation of the vehicle body safety and comfort systems, and choose the appropriate tool to do simple maintenance work, and the higher vocational students can achieve the correctly distinguish failure phenomenon of the vehicle's electrical system, and can choose the appropriate tools to do fault diagnosis and exclusion.

(4) teaching methods converge

With the higher development of modern society, changing the basic quality of the students, the traditional teaching methods no longer meet the new demands of teaching, teaching methods of the secondary and higher vocational educations must be reformed. Good teaching methods can lead to the interest of students, maximum provide for students with free development space, also improve learning outcomes, improve the sync of knowledge and ability.

"Body and Comfort system service" is a very practical curriculum, teaching methods must be integration of theory and practice, in order to understand and master the knowledge content. Therefore, the curriculum standards set the time of practice teaching accounted for $50 \%$ and the time of theory teaching is $50 \%$. The students of the secondary vocational school are not familiar with body 
and comfort system, so the knowledge is divided into circuit reading, component structure disassembly, simple maintenance when the courses are taught. Higher vocational students have the basic of the system, the course teaches symptoms of the automotive electrical system, and choose the appropriate tools to diagnose faults and troubleshooting, specific tasks from easy to difficult achieve better enhance capacity.

(5) teaching evaluation recommendations

The assessment methods of the combination of final examination, usual examination and the practical operation is Established. The each proportion is $60 \%, 20 \%, 20 \%$.

Final examination is mainly papers assessment, usual examination assess mainly attendance, discipline, safety, equipment use and team spirit, etc., and practical operation assess mainly the degree of task completion and the tool usage. This assessment method can assess students from the all aspects.

\section{References}

[1] Dj.M. Maric, P.F. Meier and S.K. Estreicher: Mater. Sci. Forum Vol. $83-87$ (1992), p. 119

[2] M.A. Green: High Efficiency Silicon Solar Cells (Trans Tech Publications, Switzerland 1987).

[1] "The guidance of the Ministry of Education about promoting the coordinated development of on secondary and higher vocational education" (faculty as [2011] No.9)

[2] Jian Zhang. The thinking on connecting from secondary and higher vocational courses [J]. Career and Education, 2012.1.

[3] Li Xun. The review the present research of the vocational courses converge [J]. System builds, 2012.13

[4] Vocational education BBS, 2012 (13): 47-52

[5] Ling Shen. The design of the curriculum standards connect from secondary and higher vocational education in engineering machinery. [J]. Vocational and Technical Education, 2013.11.

[6] Jie Jiang. The research and practice on convergence in secondary and higher vocational education [M] Beijing: China Science and Technology University Press, 2013.

( The subject comes from the Dalian Vocational and Technical Education Science Institute, project number DZKY2014001) 